\title{
PERBEDAAN MOTIVASI KERJA DAN ETOS KERJA ANTARA KARYAWAN PENDATANG DENGAN KARYAWAN NON PENDATANG YANG BEKERJA PADA HOTEL BINTANG LIMA DI BALI \\ Dewa Gede Ari Dhanendra dan Komang Rahayu Indrawati \\ Program Studi Psikologi, Fakultas Kedokteran, Universitas Udayana dodedhanendra@gmail.com
}

\begin{abstract}
Abstrak
Provinsi Bali sebagai destinasi utama wisatawan, menjadikan usaha-usaha yang bergerak di bidang pariwisata seperti hotel bintang lima tumbuh pesat sehingga menjadi daya tarik bagi tenaga kerja dari Bali maupun luar Bali untuk bekerja pada hotel bintang lima. Hal tersebut membuat pengusaha hotel bintang lima memiliki kandidat karyawan yang beragam, sehingga aspek pertimbangan lainnya dibutuhkan untuk meramalkan kinerja calon karyawannya. Motivasi kerja dan etos kerja merupakan salah satu faktor yang mempengaruhi kinerja. Oleh karena itu peneliti ingin mengetahui perbedaan motivasi kerja dan etos kerja antara karyawan pendatang dengan karyawan non pendatang yang bekerja di hotel bintang lima di Bali. Sampel penelitian diambil secara acak dengan metode two-stage cluster sampling hingga mendapatkan 134 sampel dari 13 hotel bintang lima yang tersebar di dua kabupaten dan satu kotamadya dengan. Analisis uji beda Independent Sample T-Test menunjukkan hasil yang signifikan pada variabel motivasi kerja $(\mathrm{t}=-2.325 ; \mathrm{p}=0.022 \leq 0.05)$ dan pada variabel etos kerja $(\mathrm{t}=-2.967 ; \mathrm{p}=0.004 \leq 0.05)$ yang artinya Ho ditolak. Berdasarkan hal tersebut dapat disimpulkan bahwa terdapat perbedaan motivasi kerja dan etos kerja antara karyawan pendatang dengan karyawan non pendatang yang bekerja pada hotel bintang lima di Bali.
\end{abstract}

Kata kunci: Motivasi Kerja, Etos Kerja, Karyawan Pendatang dan Non-pendatang, Hotel Bintang Lima

\begin{abstract}
Bali as the most popular destination for travellers has made all tourism companies and corporates, e.g five star hotel, rapidly develop to attract local or migrant workers to work in five star hotel in Bali. Moreover, five star hotel employer become benefited by the enormous number of employee candidates, which makes them consider the other thing that could predict worker's performance. Both work motivation and work ethic are one of the factor that contribute to employee's performances. In result, researcher disposed to acknowledge the difference between work motivation and work ethic between migrant workers and non-migrant workers which employed in five star hotel in Bali. Research sample was chosen randomly through two-stage cluster sampling which succeed to obtain 134 samples from 13 different five stars hotel. These hotels are spread out in two regencies and one city. Independent Sample T-Test was used to analyse the data. Work motivation significance number was shown in $\mathrm{t}=-2.325 ; \mathrm{p}=$ $0.022 \leq 0.05$, whilst $t=-2.967 ; \mathrm{p}=0.004 \leq 0.05$ was the significance of work ethic which means Ho rejected. In summary, the analysis shown that there was a difference between work motivation and work ethic between migrant workers and non-migrant workers which employed in five star hotel in Bali.
\end{abstract}

Keywords: Work Motivation, Work Ethic, Migrant and Non-migrant Workers, Five-star Ho 


\section{LATAR BELAKANG}

Association of South East Asia Nations Economic Community atau sering disebut Masyarakat Ekonomi ASEAN yang telah dimulai sejak tahun 2015 lalu telah membuka kesempatan kerja baru dibeberapa sektor. Perlu diketahui, dalam rumusannya tidak semua sektor pekerjaan disetujui oleh para petinggi negara-negara ASEAN. Salah satu sektor yang disetujui dalam rumusannya adalah sektor jasa di bidang pariwisata. Menteri ketenagakerjaan, M. Hanif Dhakiri dikutip dari Asdhiana (2016) mengatakan jika tenaga kerja sektor pariwisata paling siap menghadapi MEA karena standar kompetensi yang dimiliki sudah sama dengan negara-negara lain. Sektor pariwisata menurut Undang-Undang Republik Indonesia nomor 10 tahun 2009 tentang kepariwisataan pada pasal 14 ayat satu poin (f) bab VI mengenai usaha pariwisata menyebutkan salah satu jenis usaha pariwisata adalah penyedia akomodasi yang diantaranya adalah hotel, vila, pondok wisata, bumi perkemahan, persinggahan karavan, dan akomodasi lainnya yang digunakan untuk tujuan pariwisata. Data Badan Pusat Statistik Nasional menunjukkan hotel berbintang di Indonesia mengalami peningkatan jumlah dalam kurun waktu lima tahun terakhir, sehingga memiliki fenomena-fenomena yang menarik untuk diteliti. Hotel bintang di Indonesia diklasifikasikan menjadi lima klasifikasi bintang dengan syarat-syarat tertentu yang harus dipenuhi.

Penelitian ini memfokuskan pada hotel bintang lima karena beberapa alasan. Sesuai Surat Keputusan Kep22/U/VI/78 yang dikeluarkan oleh Direktorat Jenderal Pariwisata, hotel bintang lima dituntut untuk memiliki minimal 100 kamar dan dilengkapi berbagai fasilitas penunjang serta fasilitas tambahan. Jumlah kamar dan fasilitas yang beragam dibanding klasifikasi hotel bintang lainnya, akan memerlukan manajemen dengan lebih banyak karyawan untuk mengaturnya. Hal tersebut mengindikasikan hotel bintang lima membuka kesempatan kerja yang lebih besar dibanding hotel bintang lainnya. Kedua, hotel-hotel bertaraf internasional di Amerika Serikat cenderung memperkerjakan pekerja imigran karena dipandang dapat meningkatkan jumlah tamu asing dan biasanya tamu-tamu asing lebih menghargai pekerja imigran tersebut (Kappa, Nitschk, dan Shappert, 1990). Hal ini dapat menjadi indikasi bahwa hotel-hotel bintang lima yang bertaraf internasional lebih memperhitungkan isu keberagaman, dengan memperkerjakan pekerja imigran yang memiliki kemiripan kondisi seperti pekerja pendatang di Indonesia dalam organisasinya dan hal tersebut mendapat tanggapan positif dari konsumennya.

Hotel bintang lima tersebar diseluruh Indonesia dan berdasarkan data BPS Nasional serta data Dinas Provinsi Bali diketahui $40 \%$ hotel bintang lima di Indonesia berada di Bali. Pulau Bali menempati peringkat ke dua dalam sepuluh pulau terbaik di dunia (Prodjo, 2015), sehingga tidak dipungkiri
Provinsi Bali juga menempati posisi pertama dengan tingkat hunian tertinggi dengan persentase tingkat hunian sebesar $59,88 \%$ pada hotel berbintang (BPS Nasional, 2014). Sehubungan dengan adanya indikasi daya tarik penduduk pendatang untuk bekerja pada hotel bintang lima, salah satu data yang dapat menjadi gambaran lebih lanjut adalah meningkatnya jumlah penduduk migran atau pendatang di Bali. BPS Nasional mencatat penduduk migran yang masuk ke Provinsi Bali mengalami peningkatan dari tahun 2013 dan tercatat pada tahun 2014 penduduk migran yang masuk sebanyak 536.578 ribu jiwa. Jumlah tersebut memang tidak semata-mata menggambarkan jumlah penduduk migran yang bekerja pada hotel bintang lima, namun dapat dikatakan bahwa data ini menunjukkan tingginya minat penduduk migran untuk datang ke Bali.

Data mengenai jumlah tenaga kerja pendatang pada hotel bintang lima di Bali tidak diketahui secara pasti, oleh karena itu dilakukan preliminary study pada salah satu hotel bintang lima untuk mengetahui gambaran daya tarik tenaga kerja pendatang untuk bekerja pada hotel bintang lima. Contoh gambaran daya tarik tenaga kerja pendatang pada hotel bintang lima dapat dilihat pada demografi karyawan Nusa Dua Beach Hotel total memperkerjakan 627 orang karyawan yang terdiri dari 566 orang karyawan bertempat lahir di Bali sedangkan sisanya 61 orang karyawan bertempat lahir diluar Provinsi Bali. Jumlah karyawan yang memiliki tempat lahir di luar Bali di hotel ini hampir mencapai $10 \%$ dari jumlah keseluruhan karyawan.

Demografi yang berbeda ditunjukkan di hotel Hard Rock Hotel Bali tempat peneliti melakukan preliminary study. Berdasarkan data yang berhasil didapatkan, Hard Rock Hotel Bali memperkerjakan 626 orang karyawan yang 501 orang karyawannya adalah karyawan dengan tempat lahir di Bali dan sisanya sebanyak 125 orang karyawan adalah karyawan yang memiliki tempat lahir di luar Bali atau tercatat memiliki Kartu Identitas Penduduk Sementara (KIPS). Jumlah karyawan yang memiliki tempat lahir di luar Bali hampir mencapai $20 \%$ dari jumlah keseluruhan karyawan. Diketahui juga pada hotel ini terdapat 75 orang pemegang jabatan pada level management yang 25 orang diantaranya adalah pendatang atau bertempat lahir diluar Bali, sehingga dapat dilihat sekitar 33\% posisi jabatan diisi oleh karyawan pendatang. Hal ini menunjukkan bahwa $67 \%$ karyawan non pendatang sebagai pemegang jabatan, memiliki kinerja yang diakui dan masih dipercaya untuk memegang jabatan di level management.

Perbedaan kebijakan jumlah dalam memperkerjakan tenaga kerja pendatang menjadi hal yang menarik untuk diteliti, karena tentu saja perusahaan mempunyai pertimbangan tertentu dalam menentukan kebijakan. Dapat dilihat bahwa karyawan non pendatang masih menunjukkan dominasinya secara jumlah dan persentase pemegang jabatan, hal ini akan menimbulkan rasa ketidakadilan untuk karyawan 
pendatang sebagai minoritas di tempat kerjanya dan merasa memiliki kesempatan yang kecil untuk menumbuhkan karir. Dikutip dari Cochran (2009) ada sebuah studi yang menemukan bahwa ketidakadilan yang dirasakan secara terus menerus di tempat kerja berpotensi menyebabkan karyawan mengalami kerusakan psikologis dan kelelahan emosional yang dapat mempengaruhi kinerja karyawan.

Kinerja menurut Bernadin dan Russel (dalam Aziz, 2008) adalah hasil dari prestasi kerja yang telah dicapai oleh karyawan sesuai dengan fungsi dan tugasnya pada periode tertentu. Tampilnya kinerja terbaik dipengaruhi beberapa faktor, salah satunya adalah motivasi kerja dan etos kerja. Hal tersebut dibuktikan dengan penelitian dari Makta, Noor, dan Kapalawi (2013), yang menemukan terdapat pengaruh motivasi kerja terhadap kinerja perawat pelaksana di instalasi rawat inap Rumah Sakit Stella Maris Makasar. Berdasarkan penelitian tersebut, peneliti memandang motivasi kerja merupakan salah satu faktor yang memengaruhi kinerja. Etos kerja juga ditemukan memiliki pengaruh positif terhadap kinerja pegawai Rumah Sakit Umum Daerah Kayen Kabupaten Pati secara parsial (Susanti, 2013). Djasuli dan Harwida (2012) menemukan bahwa terdapat hubungan positif yang signifikan antara motivasi kerja dan etos kerja spiritual sebagai variabel moderating memengaruhi kinerja pegawai. Mengacu pada pemaparan penelitian-penelitian tersebut, dapat dismpulkan dengan mengukur motivasi kerja dan etos kerja dapat membantu pelaku usaha bintang lima untuk memprediksi kinerja yang akan ditampilkan tenaga kerja nantinya.

Motivasi kerja didenifisikan sebagai dorongan yang membuat seseorang mengerjakan suatu tugas yang memiliki arah atau tujuan tertentu (Robbins, 1998). Terkait penelitian motivasi kerja, hasil penelitian dari Pratama (2013) menemukan adanya perbedaan motivasi kerja antara orang Bali yang bekerja di Bali dengan orang Bali yang merantau di Sulawesi Tengah dimana rata-rata motivasi kerja orang Bali yang merantau di Sulawesi Tengah lebih tinggi daripada orang Bali yang bekerja di Bali. Hal ini menunjukkan adanya indikasi proses migrasi sebagai pembeda motivasi kerja seseorang. Mengacu pada hal tersebut peneliti ingin melihat bagaimana gambaran motivasi kerja non pendatang jika dibandingkan dengan pendatang yang bekerja di Bali.

Sama halnya dengan motivasi kerja, etos kerja juga memiliki peranan dalam upaya individu mencapai kinerja yang optimal. Etos kerja sendiri menurut Sinamo (2013) dapat diartikan sebagai suatu doktrin tentang kerja yang diyakini oleh seseorang atau sekelompok orang sebagai baik dan benar yang terwujud nyata secara khas dalam perilaku kerja mereka. Pengaruh budaya terhadap etos kerja juga dapat dilihat pada etos kerja orang Bali. Etos kerja orang Bali menurut hasil penelitian Sundayra (2015) yaitu yang pertama adalah orang Bali memprioritaskan upacara agama diatas pekerjaan dan yang kedua orang Bali kurang dapat memelihara waktu dengan baik ditunjukkan dengan sering datang terlambat dan pulang lebih awal saat bekerja. Penelitian tersebut menggambarkan bahwa latar belakang budaya dari daerah asal seseorang menentukan nilai-nilai yang dianut.

Adanya indikasi ketidakadilan yang dirasakan karyawan pendatang dan berpotensi memengaruhi kinerja, serta adanya pertimbangan perusahaan hotel bintang lima di Bali yang masih memercayakan karyawan non pendatang mengisi jabatan menjadi alasan kuat mengapa penelitian ini dilakukan. Diharapkan hasil penelitian ini dapat memberikan gambaran atas fenomena pada preliminary study serta menjadi gambaran atas keberagaman motivasi kerja dan etos kerja yang dimiliki pada kedua kelompok karyawan. Penelitian ini juga bertujuan untuk memberikan pertimbangan dalam mengambil keputusan dan kebijakan bagi pelaku usaha bintang lima. Dapat disimpulkan penelitian ini dilakukan untuk mengetahui perbedaan motivasi kerja dan etos kerja antara karyawan pendatang dengan karyawan non pendatang yang bekerja pada hotel bintang lima di Bali.

\section{METODE PENELITIAN}

\section{Hipotesis Penelitian}

a. Ha: Ada perbedaan motivasi kerja karyawan non pendatang dengan karyawan pendatang yang bekerja pada hotel bintang lima di Bali.

Ho: Tidak ada perbedaan motivasi kerja karyawan non pendatang dengan karyawan pendatang yang bekerja pada hotel bintang lima di Bali.

b. Ha: Ada perbedaan etos kerja karyawan non pendatang dengan karyawan pendatang yang bekerja pada hotel bintang lima di Bali.

Ho: Tidak ada perbedaan etos kerja karyawan non pendatang dengan karyawan pendatang yang bekerja pada hotel bintang lima di Bali.

\section{Variabel dan Definisi Operasional}

Variabel yang digunakan adalah status pendatang dengan non pendatang sebagai variabel bebas dan motivasi kerja serta etos kerja sebagai variabel tergantung. Pendatang adalah penduduk yang datang dari luar Provinsi Bali yang melakukan perpindahan dengan tujuan untuk menetap dengan melewati batas administratif atau beridentitas sebagai penduduk luar Provinsi Bali.

Motivasi kerja adalah proses psikologis yang dipengaruhi oleh susunan dorongan, insentif dan lingkungan kerja yang membuat individu melakukan yang terbaik dari kemampuannya saat bekerja. Sedangkan, etos kerja merupakan nilai-nilai pembentuk kepribadian seseorang dalam bekerja yang tercermin dengan sikap positif individu, keandalan, profesionalisme, inisiatif, rasa hormat, integritas 
dan rasa syukur. Motivasi kerja dan etos kerja pada karyawan akan diukur melalui kuesioner.

\section{Responden}

Populasi dalam penelitian ini adalah seluruh karyawan yang bekerja pada hotel bintang lima di Bali. Pengambilan sampel dilakukan secara acak menggunakan teknik Two-Stages Cluster Sampling, yaitu peneliti mengacak kabupaten sebagai daerah tempat pengambilan sampel kemudian tahap kedua peneliti mengacak hotel bintang lima di kabupaten yang terpilih. Sampel yang terpilih adalah karyawan dari Hotel Maya, Hotel Grand Inna Bali Beach, Hotel Prama, Hotel Inaya Putri Bali, Holiday Inn Resort Baruna, Hotel Laguna, Patrajasa, Kuta Heritage dan Melia Bali yang bersedia dan diijinkan mengisi kuesioner. Total terdapat 134 karyawan yang menjadi subjek penelitian ini.

\section{Tempat penelitian}

Pengambilan data tryout dilakukan di Nusa Dua Beach Hotel pada tanggal 27 Agustus 2016 dan pada Hotel Hard Rock Bali pada tanggal 21 September 2016. Penyebaran kuesioner penelitian kemudian dilakukan di Hotel Maya, Hotel Grand Inna Bali Beach, Hotel Prama, Hotel Inaya Putri Bali, Holiday Inn Resort Baruna, Hotel Laguna, Patrajasa, Kuta Heritage dan Melia Bali yang dimulai pada tanggal 18 Oktober 2016 sampai dengan tanggal 5 November 2016.

\section{Alat ukur}

Pengukuran motivasi kerja dan etos kerja dilakukan dengan cara memberikan kuisioner kepada subyek. Kuisioner motivasi kerja disusun berdasarkan teori dua faktor oleh Herzberg (dalam Munandar, 2008), sedangkan kuesioner etos kerja disusun berdasarkan teori tujuh hal sederhana pembentuk etos kerja oleh Chester (2007). Terdapat 44 aitem pernyataan untuk mengukur motivasi kerja dan 56 aitem pernyataan untuk mengukur etos kerja. Kedua kuesioner disusun dalam bentuk skala Likert.

Penelitian dikatakan valid jika terdapat kesamaan antara data yang terkumpul dengan data yang sesungguhnya terjadi pada objek yang diteliti dan instrumen yang digunakan memenuhi syarat (Sugiyono, 2013). Validitas yang diuji dalam penelitian ini adalah validitas isi dan validitas konstruk. Validitas isi merupakan validitas yang diestimasi melalui pengujian isi tes dengan analisis rasional atau dapat dikatakan melalui professional judgement (Azwar, 2013). Pengukuran validitas isi akan dilakukan dengan SPSS 17.0 for windows, yaitu melihat korelasi antara aitem dan total. Menurut Azwar (2012), item-item alat ukur akan dikatakan memiliki validitas yang baik apabila memiliki korelasi aitem-total lebih dari atau sama dengan $0.3(\mathrm{r} 1 \mathrm{x} \geq 0.30)$.

Pendekatan reliabilitas yang digunakan dalam penelitian ini adalah metode penyajian tunggal atau single-trial administration yang akan menghasilkan estimasi reliabilitas konsistensi internal (internal consistency) (Azwar, 2010). Hasil yang didapat dari metode single-trial administration akan dianalisis dengan Alpha Cronbach dengan bantuan program komputer SPSS 17.0 for windows dalam perhitungannya.

Terdapat dua aitem yang gugur pada skala motivasi kerja dan hasil uji validitas menunjukkan nilai koefisien korelasi aitem yang bergerak dari 0,691 - 0,960 dengan angka koefisien Alpha $(\alpha)$ sebesar 0,981 yang artinya skala ini mampu mencerminkan 98,1\% skor murni subjek. Pada skala etos kerja terdapat tiga aitem yang gugur dan hasil uji validitas menunjukkan nilai nilai koefisien korelasi aitem yang bergerak dari 0,601 - 0,948 dengan angka koefisien Alpha $(\alpha)$ sebesar 0,984 yang artinya skala ini mampu mencerminkan $98,4 \%$ skor murni subjek.

\section{Teknik analisis data}

Analisis data pada penelitian ini menggunakan Independent Sample T-Test dengan bantuan program komputer SPSS 17.0 for windows untuk mengetahui apakah ada perbedaan motivasi kerja dan etos kerja antara karyawan pendatang dengan karyawan non pendatang yang bekerja pada hotel bintang lima di Bali. Pengujian hipotesis baru dapat dilakukan setelah melewati syarat-syarat uji asumsi yaitu uji normalitas dan homogenitas. Pada penelitian ini uji normalitas menggunakan uji Skewness-Kurtosis (Nurgiyantoro, Burhan, Gunawan dan Marzuki, 2009), sedangkan untuk uji homogenitas menggunakan Levent test (Santoso, 2003) yang juga menggunakan bantuan program komputer SPSS 17.0 for windows.

\section{HASIL PENELITIAN}

\section{Karakteristik Subjek}

Subjek penelitian terdiri dari 57 karyawan yang tergolong pendatang dan 77 karyawan yang tergolong non pendatang. Mayoritas karyawan yang tergolong pendatang pada penelitian ini telah menetap di Bali lebih dari lima tahun dan $71,9 \%$ dari seluruh karyawan pendatang bersuku Jawa. Diketahui juga bahwa alasan mereka berpindah ke Bali bukanlah karena faktor ekonomi seperti upah minimum regional. Hal tersebut diketahui berdasarkan pilihan alasan yang dipilih subjek, dimana $49,1 \%$ subjek memilih alasan lainnya. Sebesar 63,2\% karyawan pendatang merasa puas terhadap gajinya, sedangkan karyawan non pendatang menunjukkan persentase yang lebih rendah yaitu $58,4 \%$ dalam kepuasan terhadap gajinya. 


\section{Deskripsi Data Penelitian}

Hasil deskripsi data motivasi kerja dan etos kerja pada masing-masing kelompok dapat dilihat pada tabel 1 dan tabel 2 .

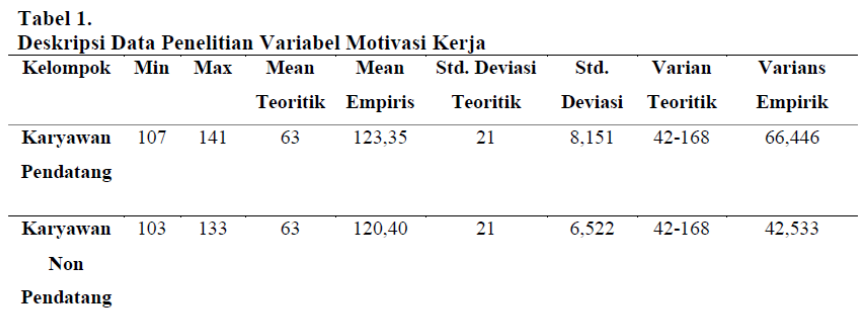

Berdasarkan tabel diatas, terlihat bahwa skor motivasi kerja terendah pada subjek penelitian berada pada kelompok karyawan non pendatang, sedangkan skor motivasi kerja tertinggi berada pada kelompok karyawan pendatang. Mean empiris menunjukkan nilai yang lebih tinggi dibandingkan dengan nilai mean empiris pada skala motivasi kerja, hal ini juga memiliki makna bahwa subjek penelitian memiliki motivasi kerja yang lebih tinggi dibanding populasinya.

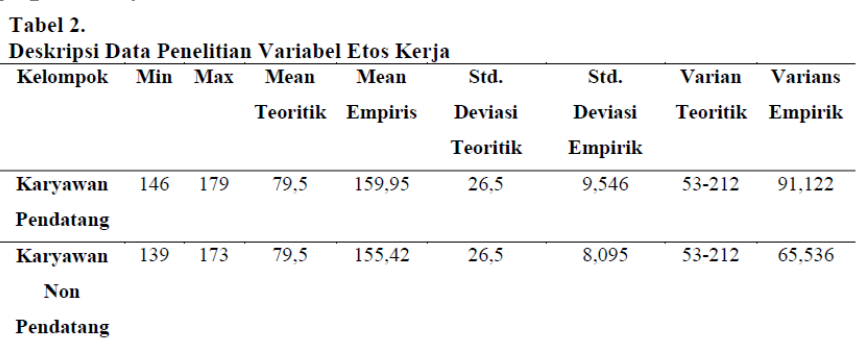

Pada tabel 2, dapat dilihat bahwa skor etos kerja terendah pada subjek penelitian berada pada kelompok karyawan non pendatang, sedangkan skor etos kerja tertinggi berada pada kelompok karyawan pendatang. Sama halnya dengan motivasi kerja, perbedaan pada mean empiris dengan mean teoritis juga ditemukan pada skala etos kerja. Mean empiris menunjukkan nilai yang lebih tinggi dibandingkan dengan nilai mean empiris pada skala motivasi kerja, hal ini juga memiliki makna bahwa subjek penelitian memiliki etos kerja yang lebih tinggi dibanding populasinya.

\section{Kategorisasi Data Penelitian}

Hasil pengkategorian skor motivasi kerja dan etos kerja dapat dilihat pada tabel 3 dan tabel 4 .

\begin{tabular}{|c|c|c|c|c|c|}
\hline \multirow{2}{*}{$\begin{array}{l}\text { Rentang Nilai } \\
\text { Motivasi Kerja }\end{array}$} & \multirow[t]{2}{*}{ Kategori } & \multicolumn{2}{|c|}{ Pendatang } & \multicolumn{2}{|c|}{ Non Pendatang } \\
\hline & & Jumlah & Persentase & Jumlah & Persentase \\
\hline$x<107$ & Sangat Rendah & 2 & $3,5 \%$ & 3 & $7,8 \%$ \\
\hline $107<x \leq 114$ & Rendah & 4 & $7,0 \%$ & 6 & $3,9 \%$ \\
\hline $114<x \leq 129$ & Sedang & 39 & $68,4 \%$ & 60 & $77,9 \%$ \\
\hline $129<x \leq 136$ & Tinggi & 7 & $12,3 \%$ & 8 & $10,4 \%$ \\
\hline $136<x$ & Sangat Tinggi & 5 & $8,8 \%$ & - & - \\
\hline Total & & 57 & $100 \%$ & 77 & $100 \%$ \\
\hline
\end{tabular}

Berdasarkan tabel 3, diketahui bahwa terdapat perbedaan kategori antara subjek dalam kelompok pendatang dengan kelompok non pendatang. Secara persentase, 68,4\% kelompok pendatang berada pada kategori sedang. Persentase yang lebih besar ditunjukkan pada kelompok karyawan non pendatang. Sebesar 77,9\% kelompok non pendatang berada pada kategori sedang. Pada kategori sangat tinggi terdapat lima orang $(8,8 \%)$ kelompok pendatang, sedangkan pada kelompok non pendatang tidak ada yang terkategori sangat tinggi.

Tabel 4.

Kategori Etos Kerja

\begin{tabular}{cccccc}
\hline \multirow{2}{*}{$\begin{array}{c}\text { Rentang Nilai } \\
\text { Etos Kerja }\end{array}$} & Kategori & \multicolumn{2}{c}{ Pendatang } & \multicolumn{2}{c}{ Non Pendatang } \\
\cline { 3 - 6 } & & Jumlah & Persentase & Jumlah & Persentase \\
\hline$x<139$ & Sangat Rendah & - & - & 1 & $1,3 \%$ \\
\hline $139<x \leq 148$ & Rendah & 5 & $8,8 \%$ & 16 & $20,8 \%$ \\
\hline $148<x \leq 166$ & Sedang & 36 & $63,2 \%$ & 51 & $66,2 \%$ \\
\hline $166<x \leq 175$ & Tinggi & 10 & $17,5 \%$ & 9 & $11,7 \%$ \\
\hline $175<x$ & Sangat Tinggi & 6 & $10,5 \%$ & - & - \\
\hline Total & & 57 & $100 \%$ & 77 & $100 \%$ \\
\hline
\end{tabular}

Pada tabel 4, dapat dilihat kembali bahwa terdapat perbedaan kategori antara subjek dalam kelompok pendatang dengan kelompok non pendatang. Sebesar 68,4\% mayoritas karyawan pendatang berada pada kategori sedang. Persentase yang lebih besar ditunjukkan pada kelompok karyawan non pendatang yaitu sebesar $66,2 \%$ berada pada kategori sedang. Walaupun menunjukkan persentase yang lebih besar untuk kategori sedang, tidak ditemukan adanya kelompok karyawan non pendatang yang tergolong pada kategori sangat tinggi. Berbeda dengan kelompok karyawan pendatang, terdapat enam orang $(10,5 \%)$ kelompok pendatang yang terkategori sangat tinggi.

\section{Uji Asumsi}

Terdapat dua uji asumsi dalam penelitian ini yaitu uji normalitas dan uji homogenitas. Hasil uji normalitas dapat dilihat pada table 5 dan hasil uji homogenitas dapat dilihat pada table 6 .

\begin{tabular}{|c|c|c|c|c|}
\hline \multicolumn{5}{|c|}{ Non Pendatang } \\
\hline & Motivasi Kerja & Etos Kerja & Motivasi Kerja & Etos Kerja \\
\hline Skewness & $-0,200$ & 0,281 & 0,369 & 0,543 \\
\hline Std. Error & 0,274 & 0,274 & 0,316 & 0,316 \\
\hline \multicolumn{5}{|l|}{ Index Ratio } \\
\hline$\left(\frac{\text { Skewness }}{\text { Std.Error }}\right)$ & -0.729 & 1,025 & 1,167 & 1,718 \\
\hline Kurtosis & 0,366 & $-0,561$ & $-0,424$ & $-0,772$ \\
\hline Std. Error & 0,542 & 0,541 & 0,623 & 0,623 \\
\hline \multicolumn{5}{|l|}{ Index Ratio } \\
\hline$\left(\frac{\text { Kurtosis }}{\text { Std.Error }}\right)$ & 0,676 & $-1,036$ & $-0,680$ & 1,239 \\
\hline
\end{tabular}

Nilai indeks rasio Skewness dan Kurtosis pada masing-masing variabel motivasi kerja dan etos kerja dikedua kelompok masih dalam rentangan -2 sampai +2 . Jika indeks rasio berada dalam rentangan -2 sampai +2 , sebaran data yang bersangkutan dapat dinyatakan normal (Nurgiyantoro, dkk, 2000). 


Tabel 6.
Hasil Uji Homogenitas Levene Test
\begin{tabular}{cccc}
\hline Levene Test for Equality of Variance & $\mathrm{F}$ & Sig. & Keterangan \\
\hline Motivasi Kerja & 3,530 & 0,062 & Data Homogen \\
\hline Etos Kerja & 2,845 & 0,094 & Data Homogen \\
\hline
\end{tabular}

Nilai $F$ tabel untuk variabel motivasi kerja menunjukkan angka 3,530 dengan probabilitas (p) sebesar 0,062, sedangkan nilai $F$ untuk variabel etos kerja menunjukkan angka 2,845 dengan probabilitas (p) sebesar 0,094. Kedua nilai probabilitas menunjukkan angka diatas 0,05 ( $p>0,05$ ). Nilai probabilitas ( $\mathrm{p}$ ) diatas 0,05 menunjukkan bahwa tidak adanya perbedaan varians antara kedua kelompok atau kedua data adalah homogen, sehingga memenuhi syarat untuk dilakukan uji komparasi dengan Independent Sample TTest pada kedua variabel.

\section{Uji Hipotesis}

Uji hipotesis pada penelitian ini menggunakan Indpendent Sample T-test yang hasilnya dapat dilihat pada table 7 .

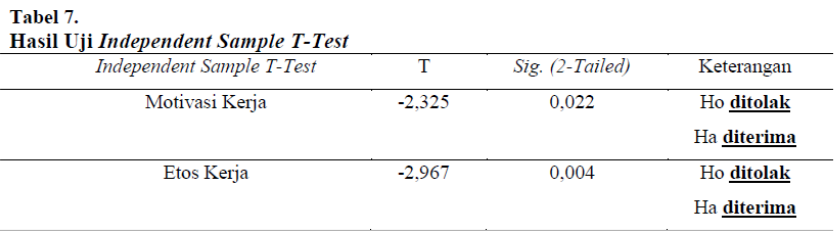

Berdasarkan tabel diatas dapat dilihat, dari hasil uji Independent Sample T-Test diketahui dari tabel bahwa $\mathrm{t}$ hitung untuk variabel motivasi kerja adalah -2,325 dengan probabilitas 0,022. Variabel etos kerja menunjukan t hitung sebesar -2,967 dengan probabilitas sebesar 0,004. Kedua variabel menunjukan angka probabilitas dibawah 0,05 $(\mathrm{p}<0,05)$ maka Ho ditolak yang berarti terdapat perbedaan motivasi kerja dan etos kerja antara karyawan pendatang dengan karyawan non pendatang yang bekerja pada hotel bintang lima di Bali.

\section{Uji Data Tambahan}

Penelitian ini melakukan analisis data tambahan berdasarkan ddata demografi subjek penelitian. Uji data tambahan bertujuan untuk melihat apakah terdapat perbedaan motivasi kerja dan etos kerja apabila ditinjau dari pendidikan, agama, suku, lama menetap, kerabat yang diajak menetap dan status kerja subjek.

\begin{tabular}{|c|c|c|}
\hline \multicolumn{3}{|c|}{$\begin{array}{l}\text { Tabel } 8 . \\
\text { Hasil Uji Mann-Whitney Etos Kerja Berdasarkan Pendidikan }\end{array}$} \\
\hline \multirow[t]{3}{*}{ Pendidikan } & Asymp. Sig. & Keterangan \\
\hline & (Karyawan Pendatang : Karyawan Non & \\
\hline & Pendatang) & \\
\hline \multirow[t]{2}{*}{ SMA } & 0,758 & Tidak ada \\
\hline & & perbedaan \\
\hline \multirow[t]{2}{*}{ Diploma I } & 0,221 & Tidak ada \\
\hline & & Perbedaan \\
\hline \multirow[t]{2}{*}{ Diplona III } & 0,063 & Tidak ada \\
\hline & & perbedaan \\
\hline \multirow[t]{2}{*}{ Sarjana } & 0,320 & Tidak ada \\
\hline & & perbedaan \\
\hline
\end{tabular}

Berdasarkan tabel 8, diketahui bahwa seluruh nilai Asymp Sig. pada masing-masing kelompok menunjukkan angka probabilitas yang lebih besar daripada 0,05 ( $\mathrm{p}>0,05)$. Probabilitas yang lebih besar dari 0,05 menunjukkan bahwa tidak terdapat perbedaan etos kerja yang signifikan antara karyawan pendatang dengan karyawan non pendatang jika ditinjau dari pendidikan.

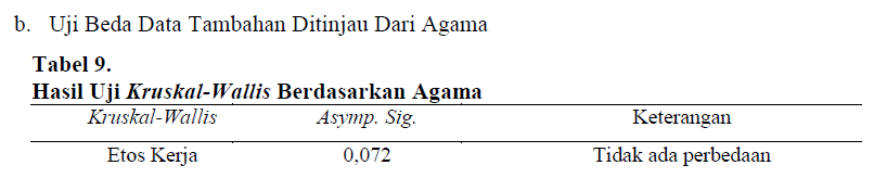

Dari tabel 9 diatas, diketahui bahwa nilai Asymp Sig. menunjukkan problalitas sebesar 0,072 yang berarti kurang dari $0,05(\mathrm{p}<0,05)$, sehingga dapat dikatakan bahwa terdapat perbedaan etos kerja antara karyawan hotel bintang lima jika ditinjau dari agama.

c. Uji Beda Data Tambahan Ditinjau Dari Suku

Tabel 10.

Hasil Uji Independent Sample T-test Berdasarkan Suku

$\begin{array}{ccc}\begin{array}{c}\text { Independent } \\ \text { Sample T-test }\end{array} & \text { Asymp. Sig. } & \text { Keterangan } \\ \text { Etos Kerja } & 0,010 & \text { Ada perbedaan }\end{array}$

Berdasarkan tabel 10, dapat dilihat bahwa pada nilai Asymp Sig. memiliki probabilitas sebesar 0,010 yang lebih rendah dari 0,05 ( $p>0,05)$. Dapat disimpulkan bahwa terdapat perbedaan etos kerja antara karyawan hotel bintang lima yang bersuku Bali dengan karyawan hotel bintang lima yang bersuku Jawa.

d. Uji Beda Data Tambahan Ditinjau Dari Lama Menetap Tabel 11. Hasil Uji Kruskal-Wallis Berdasarkan Lama Menetap

\begin{tabular}{|c|c|c|}
\hline Kruskal-Wallis & Asymp. Sig & Keterangan \\
\hline Motivasi Kerja & 0,143 & Tidak ada perbedaan \\
\hline Etos Kerja & 0,105 & Tidak ada perbedaan \\
\hline
\end{tabular}

Dapat dilihat bahwa, pada kolom Asymp Sig. untuk variabel motivasi kerja maupun variabel etos kerja memiliki probabilitas yang sama-sama lebih dari 0,05 $(\mathrm{p}<0,05)$. Hal ini menunjukan tidak adanya perbedaan motivasi kerja dan etos kerja antara karyawan yang bekerja di hotel bintang lima jika ditinjau dari lama menetapnya di Bali.

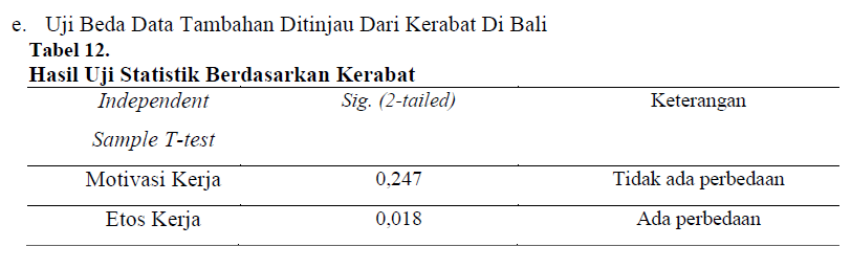

Berdasarkan tabel 12, diketahui bahwa tidak ada perbedaan motivasi kerja antara karyawan pendatang dengan non-pendatang yang tinggal bersama keluarga, ditunjukkan oleh nilai Sig. (2-tailed). yang menunjukan probabilitas sebesar 0,247 untuk variabel motivasi kerja. Hasil yang berbeda ditunjukkan pada variabel etos kerja dengan nilai probabilitas 0,018 yang lebih rendah dari 0,05 ( $\mathrm{p}<0,05)$. Berdasarkan hal tersebut, diketahui bahwa ada perbedaan etos 
kerja antara karyawan pendatang dengan non-pendatang yang tinggal bersama keluarga.

\begin{tabular}{|c|c|c|c|}
\hline \multicolumn{4}{|c|}{$\begin{array}{l}\text { Tabel } 13 . \\
\text { Hasil Uji Kruskal-Wallis Berdasarkan Status Kerja }\end{array}$} \\
\hline Jenis Uji & Status & Taraf Signifikansi & Keterangan \\
\hline \multirow[t]{2}{*}{ Komparasi } & Kerja & (Karyawan Pendatang : & \\
\hline & & Karyawan non pendatang & \\
\hline \multirow[t]{2}{*}{ Mann-Whitney } & Tetap & 0,474 & Tidak ada \\
\hline & & & perbedaan \\
\hline Mann-Whitney & Kontrak & 0,495 & Tidak ada \\
\hline
\end{tabular}

Berdasarkan tabel diatas, dapat dilihat bahwa tidak terdapat perbedaan motivasi kerja antara karyawan pendatang dan non-pendatang yang berstatus tetap ( $p>0.05)$. Motivasi kerja karyawan yang berstatus kontrak juga tidak menunjukkan perbedaan pada kedua kelompok, ditunjukkan dengan probabilitas 0,495 yang lebih dari 0,05 .

\section{PEMBAHASAN DAN KESIMPULAN}

Hasil penelitian menunjukkan Ho ditolak dan $\mathrm{Ha}$ diterima, sehingga dapat disimpulkan bahwa terdapat perbedaan motivasi kerja dan etos kerja antara karyawan pendatang dengan karyawan non pendatang yang bekerja pada hotel bintang lima di Bali. Hal ini dibuktikan dengan hasil uji komparasi menggunakan metode Independent Sample T-Test, dimana pada variabel motivasi kerja menunjukkan angka probabilitas sebesar 0,022 yang lebih kecil dari 0,05 ( $\mathrm{p}<0,05)$ dan pada variabel etos kerja menunjukkan angka probabilitas sebesar 0,004 yang lebih kecil dari 0,05 ( $\mathrm{p}<0,05)$.

Karyawan pendatang yang bekerja pada hotel bintang lima di Bali menunjukkan motivasi kerja yang lebih tinggi dibanding dengan karyawan non pendatang yang bekerja pada hotel bintang lima di Bali. Hal ini dapat dilihat dari rata-rata skor motivasi kerja yang dimiliki kedua kelompok. Kelompok karyawan pendatang menunjukkan skor rata-rata motivasi kerja sebesar 123,25, sedangkan kelompok karyawan non pendatang menunjukkan rata-rata motivasi kerja sebesar 120,40 .

Motivasi kerja merupakan proses psikologis yang dipengaruhi oleh susunan dorongan, insentif dan lingkungan kerja yang membuat individu melakukan yang terbaik dari kemampuannya saat bekerja. Beberapa literatur luar menjelaskan migrasi adalah proses perpindahan penduduk antar negara bagian, hal tersebut identik dengan proses migrasi antar provinsi yang biasa terjadi di Indonesia. Gambaran migrasi memiliki kesesuaian makna terkait tenaga kerja yang melakukan perpindahan antar provinsi seperti halnya karyawan yang berstatus pendatang dalam penelitian ini.

Adanya perbedaan motivasi kerja antara karyawan pendatang dengan karyawan non pendatang sesuai dengan pernyataan dari Boneva dan Frieze (2001) yang menjelaskan orang yang melakukan migrasi, cenderung memiliki motivasi untuk kerja dan pencapaian yang lebih tinggi jika dibandingkan dengan orang yang memilih tetap tinggal di tempat kelahirannya. Hal ini dikarenakan individu yang memiliki pengalaman melewati batasan yang ia buat seperti bermigrasi, biasanya didorong oleh motivasi untuk sukses (Zikic dalam Procter, 2014). Procter (2014) menambahkan orang-orang yang melakukan migrasi adalah tipe orang yang memiliki motivasi kerja yang tinggi dan tidak terlalu memprioritaskan keluarga. McKay (2009) lebih lanjut menyatakan perusahaan merekrut migran karena dipandang lebih komitmen, memiliki motivasi yang lebih tinggi, rendahnya turnover dan ketidakhadiran.

Pengukuran motivasi kerja dalam penelitian ini menggunakan teori motivasi kerja menurut Herzberg (dalam Munandar, 2008) yang disusun atas dasar dua faktor yang menimbulkan motivasi kerja. Dua faktor tersebut yaitu motivators yang terdiri dari faktor-faktor intrinsik dalam pekerjaan seperti tanggung jawab, pencapaian, pengakuan, konten pekerjaan, kemajuan dan hygienes yang terdiri dari faktor-faktor ekstrinsik dari pekerjaan seperti kebijakan perusahaan, supervisi, relasi antar pribadi, kondisi bekerja dan gaji.

Faktor-faktor tersebut diukur di masing-masing kelompok, baik pada kelompok karyawan pendatang maupun kelompok karyawan non pendatang. Pada kedua kelompok memiliki karakteristik dari faktor ekstrinsik di tempat kerjanya, yaitu hotel bintang lima yang telah terstandarisasi sistem manajemennya dan juga fasilitasnya. Perbedaan yang terjadi pada kelompok karyawan pendatang dengan kelompok karyawan non pendatang diindikasikan bukan terkait situasi tempat kerja sebagai faktor ekstrinsik.

Karyawan pendatang mengalami beberapa kondisi yang berbeda dengan karyawan non pendatang. Salah satu kondisi yang membedakan kelompok karyawan pendatang dengan kelompok karyawan non pendatang adalah proses adaptasi terhadap daerah baru yang harus dilalui oleh kelompok karyawan pendatang. Mayoritas karyawan pendatang telah menetap di Bali lebih dari lima tahun. Mamak (dalam Pratama, 2013) menyatakan pada lima tahun pertama migran akan mengalami pertentangan antara budaya daerah asalnya dengan budaya daerah tujuannya yang akan berdampak secara fisik dan psikologis. Dapat dikatakan bahwa mayoritas karyawan pendatang dalam peneltian ini sudah tidak mengalami pertentangan dan berhasil beradaptasi. Berbeda dengan kelompok karyawan non pendatang yang tidak mengalami proses tersebut karena seluruh subjek pada kelompok ini sejak lahir telah menetap di Bali dan tidak pernah melakukan perpindahan domisili selama lima tahun terakhir.

Alasan untuk menetap di Bali juga mengindikasikan perbedaan yang mendasari antara karyawan pendatang dengan karyawan non pendatang. Pada karyawan pendatang mayoritas memilih lainnya sebagai alasan untuk menetap di Bali, 
sedangkan alasan upah minimum regional yang lebih tinggi di Bali hanya dipilih oleh empat orang. Hal ini sesuai dengan pernyataan dari Procter (2014) yang menyebutkan faktor sosial ekonomi tidak selalu menjadi alasan utama mengapa individu melakukan migrasi. Banyak orang melakukan migrasi untuk mencari pengalaman guna menunjang rencananya dalam mencapai tujuan dan karir yang baik (Procter, 2014). Lain hal dengan kelompok karyawan non pendatang. Seluruh subjek penelitian pada kelompok ini memilih keluarga besar yang mayoritas di Bali sebagai alasan. Ketika keluarga menjadi alasan menetap di Bali maka dapat dikatakan menghidupi keluarga adalah tujuannya dari bekerja, sehingga tujuan dan rencana karirnya tidak menjadi prioritas.

Penelitian ini menunjukkan bahwa, secara persentase kepuasan gaji lebih banyak dirasakan oleh kelompok pendatang. Hasil ini serupa dengan sebuah survey yang dilakukan oleh Kementerian Pengembangan Sumber Daya Manusia dan Serikat Pekerja Migran Singapura tahun 2014 yang menunjukkan bahwa sembilan dari sepuluh pekerja migran memiliki kepuasan bekerja yang tinggi di Singapura. Gaji dalam sebuah pekerjaan serupa dengan kebutuhan dasar yang diungkapkan oleh Abraham Maslow dalam teori hierarchy of needs, hal tersebut dikarenakan gaji dapat memenuhi kebutuhan manusia serta dapat meningkatkan selfesteem, dengan kata lain, gaji membuat karyawan merasa dihargai dan mendorong untuk menunjukkan performa yang maksimal dalam karir (Whiley dalam Procter, 2014).

Terkait variabel etos kerja, probabilitas menunjukkan angka probabilitas 0,004 yang lebih rendah dari $0,05(\mathrm{p}<0,05)$ sehingga dapat dikatakan bahwa terdapat perbedaan etos kerja antara karyawan pendatang dengan karyawan non pendatang yang bekerja pada hotel bintang lima di Bali. Karyawan pendatang yang bekerja pada hotel bintang lima di Bali menunjukkan etos kerja yang lebih tinggi dibanding dengan karyawan non pendatang yang bekerja pada hotel bintang lima di Bali. Hal ini dapat dilihat dari rata-rata skor etos kerja yang dimiliki kedua kelompok. Kelompok karyawan pendatang menunjukkan skor rata-rata etos kerja sebesar 155,42, sedangkan kelompok karyawan non pendatang menunjukkan rata-rata etos kerja sebesar 159,95.

Etos kerja merupakan nilai-nilai pembentuk kepribadian seseorang dalam bekerja yang tercermin dengan sikap positif individu, keandalan, profesionalisme, inisiatif, rasa hormat, integritas dan rasa syukur. Perbedaan yang ditemukan pada penelitian ini sesuai dengan penelitian yang dilakukan sebelumnya oleh Novi dkk (2011) yang menemukan bahwa terdapat perbedaan etos kerja pada penduduk lokal dan transmigran yang bekerja sebagai petani. Para karyawan migran juga dinilai lebih terpercaya dan inovatif (Devine dalam Procter, 2014). Perusahaan yang mempekerjakan karyawan migran memandang karyawan migran cenderung lebih berkomitmen, fleksibel dan memiliki etos kerja yang lebih kuat.

Analisis tambahan yang dilakukan pada penelitian ini terkait kondisi pendatang di daerah rantauan diindikasikan sebagai peran pembeda pada gambaran etos kerja antara kelompok karyawan pendatang dengan kelompok karyawan non pendatang. Karyawan pendatang yang bekerja di Bali membawa budaya dan nilai-nilai dari daerah asalnya, hal tersebut mengindikasikan adanya perbedaan etos kerja dengan karyawan non pendatang. Kesamaan dan kedekatan budaya serta lingkungan antar budaya mempengaruhi cepat lambatnya proses adaptasi dan akulturasi (Kemenbudpar, 2004). Mayoritas karyawan pendatang pada penelitian ini adalah suku Jawa yang berasal dari pulau Jawa yang jaraknya sangat dekat pulau Bali.

Budaya yang dibawa dari daerah asalnya oleh karyawan pendatang kemudian mengalami akulturasi dengan budaya di daerah tujuan. Orientasi nilai budaya yang dianut masyarakat memiliki pengaruh terhadap etos kerja (Ismainar, 2015). Kedua budaya yang terakulturasi akan memberikan nilai-nilai baru yang nantinya akan berpengaruh terhadap etos kerja. Berbeda halnya dengan karyawan non pendatang yang sejak lahir telah menetap di Bali sehingga budaya Bali yang dianut masih sangat asli dan belum tercampur dengan budaya lain.

Dorongan untuk teracu kemasa depan yang lebih baik akan melahirkan semangat profesionalisme. Hal tersebut yang memulai membentuk etos kerja pada masyarakat (Ismainar, 2015). Seperti dipaparkan sebelumnya, mayoritas karyawan pendatang pada penelitian ini tidak memilih UMR sebagai alasan, namun memilih alasan lainnya. Para pekerja migran tidak lagi menjadikan faktor ekonomi dan sosial sebagai alasan utamanya untuk melakukan migrasi, namun cenderung memiliki tujuan untuk mencari pengalaman guna pengembangan karir. Pengembangan karir sebagai tujuan merupakan salah satu cara dalam menata masa depan yang lebih baik

Faktor ketiga yang diindikasikan memengaruhi etos kerja yaitu motivasi intrinsik individu. Menurut Ismainar (2015) individu yang memiliki etos kerja yang tinggi adalah individu yang bermotivasi tinggi. Etos kerja merupakan suatu pandangan dan sikap, yang tentunya didasari oleh nilai-nilai yang diyakini seseorang. Keyakinan inilah yang menjadi motivasi kerja (Ismainar, 2015) . Hal ini sesuai dengan penemuan dalam penelitian ini dimana etos kerja yang lebih tinggi ditunjukkan pada karyawan non pendatang berbanding lurus dengan motivasi kerja yang juga lebih tinggi dibandingkan dengan karyawan non pendatang.

Berdasarkan seluruh pemaparan pada penelitian ini, dapat disimpulkan bahwa terdapat perbedaan motivasi kerja dan etos kerja antara karyawan pendatang dengan karyawan non pendatang yang bekerja pada hotel bintang lima di Bali. 
Karyawan pendatang menunjukkan rata-rata skor motivasi kerja dan etos kerja yang sedikit melampaui non pendatang. Hal ini juga dibuktikan dengan beberapa hasil uji data tambahan seperti agama, lama menetap, alasan menetap, kerabat, kepuasan gaji, kenyamanan, suhu, kebisingan, yang juga menunjukkan bahwa terdapat perbedaan motivasi kerja dan etos kerja karyawan pendatang dan non-pendatang.

Adapun saran yang dapat diberikan bagi perusahaan hotel bintang lima, diharapkan dapat memberikan pelatihan serta pengembangan yang tepat pada karyawan guna meningkatkan motivasi kerja serta etos kerja bagi. Bagi karyawan, penelitian ini diharapkan dapat memberikan gambaran mengenai motivasi kerja dan etos kerja, sehingga dapat meningkatkan kualitas diri sebagai karyawan. Sedangkan bagi pemerintah, diharapkan dapat membenahi sistem administrasi dan informasi terhadap tenaga kerja yang akan melakukan migrasi serta membekali calon karyawan dengan pelatihan-pelatihan yang tepat agar siap memasuki dunia kerja. Saran bagi peneliti selanjutnya adalah melakukan pengacakan aitem yang tidak mudah diprediksi, memperluas subyek hotel bintang lima, mengurangi jumlah aitem, melakukan pengadministrasian kuisioner tanpa perantara, dan melakukan replikasi dengan mengganti variabel.

\section{DAFTAR PUSTAKA}

Arikunto, S.. (2014). Prosedur penelitian suatu pendekatan praktik. Jakarta: Rineka Cipta.

Anoraga, P.. (2016). Psikologi kerja. Jakarta: Rineka Cipta.

Anoraga, B. (2015). Motivasi Kerja Islam Dan Etos Kerja Islam Karyawan Bank Jatim Syariah Cabang Surabaya. Skripsi. Fakultas Ekonomi dan Bisnis Universitas Airlangga. Surabaya.

Asdhiana, M. (2016, January). Menaker: sektor pariwisata paling siap hadapi MEA. Kompas. Diakses dari http://travel.kompas.com/read/2016/01/08/093819127/Men aker.Sektor.Pariwisata.Paling.Siap.Hadapi.MEA

Aziz, A, (2008). Kinerja organisasi dinas pendapatan daerah provinsi daerah khusus ibukota jakarta dengan pendekatan systems thinking dan system dynamics. Disertasi. Program Pasca Sarjana Fakultas Ilmu Sosial Dan Ilmu Politik Departemen Ilmu Administrasi, Jakarta.

Badan Pusat Statistik. (2015). Jumlah Akomodasi, Rata-rata Pekerja dan Jumlah Tamu per Hari Menurut Provinsi, Tahun 2015 (Hotel Bintang). BPS Nasional. Jakarta.

Badan Pusat Statistik. (2015). Jumlah Akomodasi, Rata-rata Pekerja dan Jumlah Tamu per Hari Menurut Provinsi, Tahun 2015 (Akomodasi Lainnya). BPS Nasional. Jakarta.

Badan Pusat Statistik. (2014). Tingkat Penghunian Kamar pada Hotel Bintang Menurut Provinsi Tahun 2004-2014 (Persen). BPS Nasional. Jakarta.

Badan Pusat Statistik. (2015). Statistik mobilitas penduduk dan tenaga kerja. Badan Pusat Statistik. Jakarta: Badan Pusat Statistik.
Boneva, B.S., Frieze, I.H. (2001). Toward a Concept of a Migrant Personality. Journal of Social Issues, Vol. 57, No. 3, 2001, pp. 477-491.

Burhannudin, Y. M.. (2008). bali yang hilang pendatang, islam, dan etnisitas di bali. Yogyakarta: Kanisinus.

Chester, E.. (2007). Reviving work ethic. Austin: Greenleaf Book Group Press.

Chowhan, J., Zeytinoglu, I.U., Cooke G.B., “Are Immigrants” Pay and Benefits Satisfaction Different than Canadian-born? $\begin{array}{llll}\text { Industrial } & \text { Relations. } & 67(1) . & \mathrm{P}\end{array}$ DOI:10.7202/1008193ar.

Cochran, C. (2009, September). Study: workplace in justices affect employee performance. Daily Skiff. Diakses dari https://www.tcu360.com/story/study-workplace-injusticesaffect-employee-performance-12285685/

Dawson, C. G., Veliziotis, M. \& Hopkins, B. 2014. Assimilation of the migrant work ethic. Working Paper. Department of Economics, University of Bath. United Kingdom.

Deswarati, Rahardjo dan Djudi. (2013). Pengaruh Penempatan Terhadap Motivasi Kerja Dan Kinerja Karyawan (Studi Pada Karyawan Pt. Astra International, Tbk-Daihatsu Malang). 4(2).

Dinas Pariwisata Provinsi Bali. (2015). Direktori pariwisata bali 2015. Denpasar: Dinas Pariwisata Provinsi Bali.

Djakfar, M. (2012). Etika bisnis: menangkap spirit ajaran langit dan pesan moral ajaran bumi. Jakarta: Penebar Plus.

Djasuli \& Harwida, (2011). Etos Kerja Spiritual sebagai Moderator Hubungan antara Motivasi Kerja dengan Kinerja Pegawai Negeri Sipil. 4, 103-109.

Enz, C.A. 2010. Handbook of applied hospitality strategy. United State of America: Sage Publication.

Erina. (2013). Hubungan antara kemandirian dengan penyesuaian diri pada mahasiswa baru yang merantau di kota malang. Skripsi. Program Studi Psikologi Universitas Barwijaya, Malang.

Hasibuan Malayu, (2000). Manajemen sumber daya manusia. Jakarta: Bumi Aksara,

Hasibuan Malayu, (2003). Manajemen sumber daya manusia edisi revisi. Jakarta: Bumi Aksara.

Herniyani, T.. (2012). Modul pengantar manajemen. modul. Sumatera Utara: Tri Guna Dharma.

Hikmah, R. (2003). Etos kerja pedagang perantau minangkabau dalam perspektif nilai budaya minangkabau. Skripsi. Fakultas Keguruan dan Ilmu Pendidikan Universitas Sebelas Maret, Surakarta.

Husni, I. (2014). Hubungan Etos Kerja Dengan Kinerja Guru Di SMK Negeri 1 Lubuk Sikaping. Jurnal Administrasi Pendidikan. 2(1), 342-381.

Ibnu. (2014, March). Bali, surga terindah di dunia. Ghiboo. Diakses dari http://ghiboo.com/2014/03/20/bali-surga-terindahdunia/.

Ismainar, H.. (2015). Manajemen unit kerja. Sleman: Deeppublish.

Ivancevich, J.M., Konopaske, R., Matteson, M.T.. (2005). Perilaku dan manajemen organisasi edisi ketujuh. Jakarta: Erlangga.

Kanfer, R., Chen, G., Pritchard, R.D.. (2008). Work motivation past, present, and future. New York: Routledge.

Kappa, M.M., Nitschke, A., Shappert, P.B.. (1990). Managing housekeeping operation. Michigan: AHMA. 
Undang-Undang Republik Indonesia Nomor 10.Tahun 2009 tentang Kepariwisataan.

Kementrian Kebudayaan dan Pariwisata. (2004). Kalpataru Majalah Arkeologi. 17. 83.

Keputusan menteri Kebudayaan dan Pariwisata Nomor KM.3/HK.001/MKP.02 tentang Penggolongan Kelas Hotel.

Kesepakatan Bersama Gubernur Bali dengan Bupati dan Walikota seBali Nomor 153 Tahun 2003 tentang Pelaksanaan Tata Tertib Administrasi Kependudukan di Provinsi Bali.

Kurniati, A. (2007). Industrialisasi dan migrasi tenaga kerja sektor di kota cilacap. Skripsi. Fakultas Teknik Universitas Diponegoro, Semarang.

Lembaga Sertifikasi Profesi Pariwisata Bali. (April 2015). Berita arsip peluang tantangan MEA. LSP Bali. http://lspbali.or.id/?cat=17.

Lingga, R.W.W.L., \& Tuapattinaja, J.M.R. 2012. Gambaran Virtue Mahasiswa Perantau. Jurnal Predicara (1) 2. 59-68.

Makta, L., Noor, N.B., Kapalawi, I. (2013). Pengaruh Motivasi Kerja Dengan Kinerja Perawat Pelaksana Di Unit Rawat Inap RS. Stella Maris Makassar. Diunduh dari http://repository.unhas.ac.id/bitstream/handle/123456789/5 921/jrnal.pdf 27 April 2015

Mantra, I.B..(2000). Demografi umum. Yogyakarta: Pustaka Pelajar.

McKay, S. (2009). Employer use of migrant labour-motivations, experiences and HR responses. ISBN 978-0-9559264-6-4

Moktis, E. (2014). Analisis perbedaan motivasi kerja karyawan asli papua dan non papua pada pt. medco papua hijau selaras. Skripsi. Fakultas Ekonomi dan Bisnis Universitas Muhammadiyah Malang, Malang.

Ministry of Manpower. (Desember 2014). Foreign Worker Survey $2014 . \quad$ Diakses dari http://www.mom.gov.sg/ /media/mom/documents/pressreleases/2014/foreign\%20worker\%20survey\%202014.pdf 12 Desember 2016

Munandar, A. S.. (2008). Psikologi industri dan organisasi. Jakarta: Universitas Indonesia.

Mullins, L.J. (2010). Management \& organisational behavior ninth edition. United Kingdom: Pearson Education Limited

Nababan, P.B.E. (2011). Pengukuran kinerja pemerintah daerah berdasarkan laporan akuntabilitas kinerja instansi pemerintah studi kasus pada bapeda pemkab serdang bedagai. Skripsi. Fakultas Ekonomi Universitas Sumatera Utara, Sumatera.

Novi, N. (2011). Etos kerja penduduk lokal dan transmigran. Skripsi. Fakultas Ilmu Sosial dan Ilmu Politik Universitas Bengkulu, Bengkulu.

Novliadi, F. (2009). Hubungan antara organization-based self-esteem dengan etos kerja. (Makalah tidak dipublikasikan). Fakultas Psikologi Universitas Sumatera Utara, Medan.

Nurgiyantoro, B. Gunawan. Marzuki. (2009). Statistik terapan untuk penelitian ilmu-ilmu sosial. Yogyakarta: Gadjah Mada University Press.

Pemerintah Provinsi Bali. 2003. Kesepakatan Bersama Gubernur Bali dengan Bupati/Walikota seBali. Gubernur Bali. Denpasar.

Peraturan Menteri Pariwisata dan Ekonomi Kreatif Nomor PM.53/HM.001/MPEK. Tahun 2013 tentang Standar Usaha Hotel.
Perkasa, S. (2015, December). Persaingan ketat pasar tenaga kerja di MEA. Metro tv. Diakses dari http://telusur.metrotvnews.com/read/2015/12/14/201019/pe rsaingan-ketat-pasar-tenaga-kerja-di-mea

Permatasari, A.D., Sarwono, S.W., Novianti, A. (2006). Hubungan Antara Prasangka Terhadap Orang Jawa Dengan Etos Kerja Pada Masyarakat Bali Yang Bekerja. Jurnal Psikologi Sosial. 12(3). 181-191.

Peterson, C., \& Seligman, M. E. P. The values in action (via) classification of strengths. Washington, DC: American Psychological Association.

Prodjo, W. A. (2015, July). 10 peringkat pulau terbaik di dunia, bali nomor dua. Kompas. diakses dari http://travel.kompas.com/read/2015/07/16/170200827/10.P eringkat.Pulau.Terbaik.di.Dunia.Bali.Nomor.Dua?page=all

Procter, Michael (2014) The Motivation Levels of a Diverse Workforce in a Large Retail Organisation in Ireland. Undergraduate thesis, Dublin, National College of Ireland.

Poniman, F., Nugroho, I., Azzaini, J.. (2006). Kubik leadership. Jakarta: Hikmah.

Pratama, A. (2013). Perbedaan Motivasi Kerja Antara Orang Bali Yang Bekerja Di Bali Dengan Orang Bali Yang Merantau Di Sulawesi Tengah. Skripsi. Program Studi Psikologi Fakultas Kedokteran Universitas Udayana, Denpasar.

Purwati, S. (2011). Pengaruh Motivasi Kerja terhadap Kinerja Karyawan PT. Anindya Mitra Internasional. Jurnal Manajemen Bisnis. 1(1),

Riggio, R.E.. (2009). Introduction to industrial/organizational psychology fifth edition. United States of America: Pearson Prentice Hall.

Robbins, S. P. (1998). Organizational behavior: concept, controversies, applications 8th ed. New Jersey: Prentince Hal.

Saydam, G.. (2000). Manajemen sumber daya manusia (human resources management): suatu pendekatan mikro (dalam tanya jawab) cetakan ke-2. Jakarta: Penerbit Djambatan.

Siagian, S.P.. (2006). Manajemen sumber daya manusia, edisi i cetakan ketiga belas. Jakarta: Bumi Aksara.

Subakti, A. G. (Juli 2015). Hal positif bila bekerja di hotel. Binus. Diakses dari http://hotelmanagement.binus.ac.id/2015/07/24/hal-positif-bila-kerjadi-hotel/.

Sinamo, J. (2013). 8 etos kerja profesional 11 ed.. Jakarta: Insitut Darma Mahardik.

Sundayra, L. (2015). Bentuk culture shock dan strategi adaptasi orang jepang yang bekerja di bali terhadap etos kerja orang bali. Skripsi. Program Studi Sastra Jepang Fakultas Ilmu Budaya Universitas Gajah Mada, Yogyakarta.

Sugiyono. (2014). Metode penelitian kuantitatif, kualitatif, dan r\&d. Bandung: Alfabeta.

Surat Keputusan Direktorat Jenderal Pariwisata, Pos dan Telekomunikasi Nomor 22/U/VI Tahun 1978 tentang Klasifikasi Hotel.

Surat Edaran Gubernur Bali Nomor . 470/1159/B.T.Pem Tahun 2002 tentang Pedoman Operasional Pendaftaran penduduk di Provinsi Bali.

Surat Keputusan Menteri Perhubungan Republik Indonesia Nomor PM.10/PW.301/PHB. Tahun 1977 tentang Klasifikasi Hotel 
Surat Keputusan Menteri Pariwisata, Pos dan Telekomunikasi Nomor KM 37/PW.340/MPPT. Tahun 1986 tentang Persyaratan Usaha Pengelolaan Hotel.

Surat Keputusan Menteri Perhubungan Nomor 241/II Tahun 1970 tentang Peraturan Pokok-pokok Usaha Hotel.

Susanti, A.R. (2013). Pengaruh gaya kepemimpinan, kedisiplinan, dan etos kerja terhadap kinerja pegawai pada rsud kayen kabupaten pati. Skripsi. Program Studi Manajemen Fakultas Ekonomi Universitas Muria Kudus, Kudus.

Sutisna, H. (2008). Analisis Hubungan Motivasi Kerja Dengan Etos Kerja Karyawan. Skripsi. Program Sarjana Ekstensi Manajemen Agribisnis Institut Pertanian Bogor. Bogor.

Tanjung, R.M. (2008). Perbedaan etos kerja pada wiraswasta etnis madura dengan etnis minangkabau di perantauan. Skripsi. Program Studi Psikologi Fakultas Ilmu Sosial dan Ilmu Politik Universitas Muhammadiyah Malang, Malang.

Todaro, M.P., Smith. (2003). Pembangunan ekonomi di dunia ketiga jilid 1. Jakarta: Erlangga.

Ward, Collin dan Anthony Kennedy. 1983. Measurement of SocialCultural Adaptation. Singapore: National University of Singapore.

Yusuf, A. M. (2014). Metode penelitian: kualitatif, kuantitatif dan penelitian gabungan edisi pertama. Jakarta: Prenadamedia Group. 